\title{
Comparison of the anaerobic microbiota of deep-water Geodia spp. and sandy sediments in the Straits of Florida
}

\author{
Wolfram M Brück ${ }^{1,2,6}$, Thomas B Brück ${ }^{3,6}$, William T Self ${ }^{4}$, John K Reed ${ }^{5}$, Sonja S Nitecki \\ and Peter J McCarthy ${ }^{1}$ \\ ${ }^{1}$ Center for Marine Biomedical and Biotechnology Research, Harbor Branch Oceanographic Institute at \\ Florida Atlantic University, Fort Pierce, FL, USA; ${ }^{2}$ Centre of Applied Marine Biotechnology, Letterkenny \\ Institute of Technology, Letterkenny, County Donegal, Republic of Ireland; ${ }^{3}$ Department of Chemistry and \\ Biochemistry, Center of Excellence in Biomedical and Marine Biotechnology, Florida Atlantic University, \\ Boca Raton, FL, USA; ${ }^{4}$ Department of Molecular Biology and Microbiology, University of Central Florida, \\ Orlando, FL, USA and ${ }^{5}$ Center for Ocean Exploration and Deep Sea Research, Harbor Branch Oceanographic \\ Institute at Florida Atlantic University, Fort Pierce, FL, USA
}

\begin{abstract}
Marine sediments and sponges may show steep variations in redox potential, providing niches for both aerobic and anaerobic microorganisms. Geodia spp. and sediment specimens from the Straits of Florida were fixed using paraformaldehyde and $95 \%$ ethanol $(\mathrm{v} / \mathrm{v})$ for fluorescence in situ hybridization (FISH). In addition, homogenates of sponge and sediment samples were incubated anaerobically on various cysteine supplemented agars. FISH analysis showed a prominent similarity of microbiota in sediments and Geodia spp. samples. Furthermore, the presence of sulfate-reducing and annamox bacteria as well as other obligate anaerobic microorganisms in both Geodia spp. and sediment samples were also confirmed. Anaerobic cultures obtained from the homogenates allowed the isolation of a variety of facultative anaerobes, primarily Bacillus spp. and Vibrio spp. Obligate anaerobes such as Desulfovibrio spp. and Clostridium spp. were also found. We also provide the first evidence for a culturable marine member of the Chloroflexi, which may enter into symbiotic relationships with deep-water sponges such as Geodia spp. Resuspended sediment particles, may provide a source of microorganisms able to associate or form a symbiotic relationship with sponges.

The ISME Journal (2010) 4, 686-699; doi:10.1038/ismej.2009.149; published online 21 January 2010

Subject Category: microbial ecology and functional diversity of natural habitats

Keywords: anaerobic culture; FISH; Geodia spp.; marine sediment
\end{abstract}

\section{Introduction}

Sponges contribute significantly to the total biomass of the tropical reef fauna and may dominate the benthic community in the Caribbean and other tropical waters (Wilkinson and Cheshire, 1990). As filter feeders, sponges process large quantities of seawater removing significant amounts of suspended particles and mircoorganisms (Duckworth et al., 2006). Overall, microorganisms may constitute up to $60 \%$ of the tissue biomass in sponges

Correspondence: PJ McCarthy, Center for Marine Biomedical and Biotechnology Research, Harbor Branch Oceanographic Institute at Florida Atlantic University, 5600 US 1 North, Fort Pierce, FL 34946, USA.

E-mail: PMcCart5@hboi.fau.edu

${ }^{6}$ These two authors contributed equally to this work.

Received 26 August 2009; revised 20 November 2009; accepted 2 December 2009; published online 21 January 2010 ('bacteriosponges') (Reiswig, 1981). Sponges and their microbiota have been intensively studied for their biochemical profiles and it has been shown that species-specific microbial communities differ from those in ambient seawater with certain sponges hosting a uniform microbial population in different oceans (Vacelet and Donadey, 1977; Wilkinson, 1978; Schmidt et al., 2000; Webster and Hill, 2001; Hentschel et al., 2002).

Similarly, estuarine and coastal marine sediments and their microbial communities have been studied in detail for a number of years for their biogeochemical significance (Skyring, 1987; Takii and Fukui, 1991). These, frequently muddy, shallow water sediments may contain up to $3 \times 10^{9}$ cells ml $\mathrm{m}^{-1}$ and show a clear seasonal variability in their geochemical and microbial composition (Musat et al., 2006). The microbiota associated with sediments retrieved from deep-water environments have also been studied for some time (Kato et al., 1997; 
Colquhoun et al., 1998; Luna et al., 2004, 2006; Wang et al., 2004). However, it is currently uncertain if these benthic sediments, which do not undergo significant seasonal changes in their geochemical and microbial composition, host specific microbial communities. Although the sediment microbial community has been shown to be dominated by members of the Planctomycetes, the Cytophagal Flavobacterium group, Gammaproteobacteria and bacteria of the Desulfosarcina/Desulfococcus group, the role and importance of anaerobes such as sulfatereducing bacteria (SRB) and methanogenic archaea have been well documented (Purdy et al., 2001, 2003; Loy et al., 2002; Dalsgaard et al., 2005; Musat et al., 2006).

Both sponges and marine sediments show steep variations in redox potential. Hoffmann et al. (2005) showed that the oxygen concentrations in Geodia barretti, one of the most ancestral demosponges with origins in the early Cambrian era, is strongly dependent on pumping activity, leading to anoxia in parts of the tissue and the canal system (Gruber and Reitner, 1991; Hoffmann et al., 2005). This anoxia seemed to be a common feature of living Geodia specimens and did not influence their survival while providing an environment favorable for the growth of symbiotic anaerobes. Furthermore, it was shown that in actively pumping Geodia individuals, the cortex and the subcortical spaces were well oxygenated but that the oxygen levels were depleted 4-6 mm below the sponge surface. In non-pumping individuals, oxygen was depleted directly beneath the cortex and diffusive oxygen consumption could be observed in the overlying water.

It may be assumed that anoxia is responsible for regulating the bacterial biota in sponges and marine sediments and may thus be responsible for seasonal fluctuations in the shallow water sediment microbiota. In turn, anoxia in sponges may benefit the sponge host by providing an environment favorable for chemoautotrophic microbial processes that contribute to sponge nutrition (Taylor et al., 2007). Therefore, it would be expected that although sponges and marine sediments may provide similar environments, sponges would harbor bacteria that would specifically aid in nutrient assimilation and cycling.
In this study, we used a combination of anaerobic culture and fluorescence in situ hybridization (FISH) with a comprehensive suite of probes to compare the microbiota of marine sediments and Geodia spp. collected from the Straits of Florida to detect microbiota important in deep-water nutrient cycling and sponge symbiosis. Particular consideration was given to anaerobic microbiota that are not commonly found in seawater to determine whether marine sediments may act as a reservoir for sponge associated microorganisms.

\section{Materials and methods}

All chemicals were obtained from Sigma Chemical Co. (St Louis, MO, USA). PCR reactions were performed using IQ Master Mix from BioRad (Hercules, CA, USA). Restriction enzymes were obtained from Promega (Madison, WI, USA). Pre-formulated Nutrient Broth, Marine Agar, Brain Heart Infusion Agar, Sabouraud-Dextrose Agar and Marine Broth were prepared according to the manufacturer's instructions unless stated otherwise and supplemented with cysteine $100 \mu \mathrm{g} \mathrm{ml}^{-1}$ (DIFCO Laboratories, Detroit, MI, USA).

\section{Sample collection and treatment}

Collection of sponge specimens and sediment samples (top $10 \mathrm{~cm}$ of the seafloor) was performed on two separate research expeditions (April 2005 and August 2005) to the Straits of Florida using the R/V Seward Johnson and the Johnson-Sea-Link I (JSL I) research submersible. Collection sites and depths are given in Table 1. All sponge specimens and sediments were handled with nitrile examination gloves. Sponges were identified using standard spicule analysis. Approximately $10 \mathrm{~g}$ of each sponge specimen or $10 \mathrm{~g}$ of each sediment sample was homogenized under sterile conditions for $3 \mathrm{~min}$ $\left(25^{\circ} \mathrm{C}\right)$ in $100-\mathrm{ml}$ sterile Artificial Seawater $(\mathrm{pH}$ : 7.2) using a commercial Waring blender (Waring Laboratory Science, Torrington, CT, USA). This homogenate was then used to establish bacterial cultures on solid agar plates. Intact specimens of sponge tissue were shock frozen at $-80{ }^{\circ} \mathrm{C}$ in $50 \%$ (v/v) glycerol.

Table 1 Collection sites

\begin{tabular}{|c|c|c|c|c|c|c|}
\hline Sample No. & Taxa & Lattitude & Longitude & Location & Country & Depth (m) \\
\hline 10-VIII-05-1-202 & Sediment & $24^{\circ} 14.0132^{\prime} \mathrm{N}$ & $82^{\circ} 18.0236^{\prime} \mathrm{W}$ & Florida, Pourtales Terrace & USA & 670 \\
\hline 2-VIII-05-1-201 & Sediment & $26^{\circ} 57.0494^{\prime} \mathrm{N}$ & $79^{\circ} 59.2467^{\prime} \mathrm{W}$ & Florida, Jupiter Reef & USA & 233 \\
\hline 12-IV-05-1-201 & Sediment & $26^{\circ} 31.3488^{\prime} \mathrm{N}$ & $78^{\circ} 56.7606^{\prime} \mathrm{W}$ & Grand Bahama Island, Freeport & Bahamas & 644 \\
\hline 9-VIII-05-1-201 & Sediment & $24^{\circ} 21.8081^{\prime} \mathrm{N}$ & $81^{\circ} 50.7809^{\prime} \mathrm{W}$ & Florida, Pourtales Terrace & USA & 191 \\
\hline 6-VIII-05-1-201 & Sediment & $25^{\circ} 41.8835^{\prime} \mathrm{N}$ & $79^{\circ} 51.9809^{\prime} \mathrm{W}$ & Florida, Miami Terrace Escarpment & USA & 342 \\
\hline HBOM 003:01040 & Geodiidae & $26^{\circ} 11.7081^{\prime} \mathrm{N}$ & $79^{\circ} 59.2363^{\prime} \mathrm{W}$ & Florida, Miami Terrace Escarpment & USA & 304 \\
\hline HBOM 003:01041 & Geodiidae & $25^{\circ} 41.8835^{\prime} \mathrm{N}$ & $79^{\circ} 51.9809^{\prime} \mathrm{W}$ & Florida, Miami Terrace Escarpment & USA & 341 \\
\hline HBOM 003:01042 & Geodiidae & $24^{\circ} 43.9859^{\prime} \mathrm{N}$ & $80^{\circ} 25.6972^{\prime} \mathrm{W}$ & Florida, Pourtales Terrace & USA & 197 \\
\hline
\end{tabular}


Fluorescence in situ hybridization

FISH with ribosomal RNA-targeted probes was carried out using a variety of probes targeting archaea, common classes of bacteria, and selected anaerobic bacteria (Table 2). Results of microscopic counting were corrected by subtracting fluorescence signals of the probes with that of nonsense probe NONEUB (NON-EUB338), which was previously shown not to hybridize with any prokaryotic cells (Amann et al., 1990; Wallner et al., 1993). All probes were synthesized and monolabelled at the $5^{\prime}$ end with Cy3 (Ex 552 nm, Em 568 nm) by Sigma-Genosys (Dublin, Ireland). Approximately $1 \mathrm{ml}$ of sponge homogenate or $1 \mathrm{ml}$ of sediment homogenate was fixed in $10 \mathrm{ml}$ of either $95 \%(\mathrm{v} / \mathrm{v})$ ethanol (for Gram-positive bacteria) or $4 \%$ (w/v) paraformaldehyde in phosphate-buffered saline $(\mathrm{pH} \mathrm{7.2,} \mathrm{for}$ Gram-negative bacteria) overnight. Fixed samples in 1-ml aliquots were washed three times in phosphate-buffered saline and resuspended in a mixture of $150 \mu \mathrm{l}$ phosphate-buffered saline and $150 \mu \mathrm{l}$ of $96 \%(\mathrm{v} / \mathrm{v})$ ethanol for storage at $-20^{\circ} \mathrm{C}$ until further use.

For hybridization, $1 \mathrm{ml}$ of fixed sample was centrifuged at $2000 \times g$ for $2 \mathrm{~min}$ to remove large particulate matter. A volume of $100 \mu \mathrm{l}$ of centrifuged sample was added to Epoxy-printed three well (14-mm diameter) microscope slides (Menzel, Braunschweig, Germany) and dried at room temperature. Slides were dehydrated in ethanol (50, 80 and $96 \%(\mathrm{v} / \mathrm{v})$ for $3 \mathrm{~min}$ each). While slides dried, $1 \mathrm{ml}$ of hybridization buffer containing $0.9 \mathrm{M} \mathrm{NaCl}, 0.02 \mathrm{M}$ TrisHCl, and $0.01 \%$ (w/v) sodium dodecyl sulfate was prepared. The formamide concentration of the hybridization buffer was adapted according to the individual probe's requirements with high performance liquid chromatography grade water being added to bring the final volume to $1 \mathrm{ml}$. Hybridization buffer $10 \mu \mathrm{l}$ was added to $1 \mu \mathrm{l}$ of the appropriate probe (50 ng $\mu^{-1}$ ) and then added to the sample slide. The remaining buffer solution was poured over a piece of tissue paper that was added to a $50-\mathrm{ml}$ centrifuge tube in which the sample slide was placed. The tube was then placed horizontally with the cap tightly closed in a hybridization oven at $46{ }^{\circ} \mathrm{C}$ for $3 \mathrm{~h}$. After hybridization, the buffer was removed from the sample using a small amount of preheated $\left(48^{\circ} \mathrm{C}\right)$ washing buffer containing $0.02 \mathrm{M}$ TrisHCl, $\quad 0.01 \mathrm{M}$ ethylene-diaminetetraacetic acid and 5-900 mM NaCl, depending on probe requirements. For total counts, 50 nM SYTO 9 (Invitrogen, Dun Laoghaire, Ireland) was added to the washing buffer. After all liquid was removed from the slide, $500 \mu \mathrm{l}$ of the washing buffer was added to the sample slide with a further $1 \mathrm{ml}$ of washing buffer being poured over a piece of tissue paper that was added to a new 50-ml centrifuge tube. The sample slide was then placed horizontally into the new tube, which was capped tightly and placed in a hybridization oven at $48{ }^{\circ} \mathrm{C}$ for $15 \mathrm{~min}$. After washing, the slide was dipped in ice-cold high performance liquid chromatography grade water for $3 \mathrm{~s}$ and air dried. Slides were stored at $-20^{\circ} \mathrm{C}$ until use. For analysis, one drop of SlowFade-Light Antifade Kit component A (Invitrogen) was added to the slide. Organisms were evaluated using an Olympus IX51 microscope (Olympus UK, London, UK) with epifluorescence attachment (Olympus U-RFL-T) and appropriate filter sets. Image analysis was performed using an Olympus DP70 camera system and Olympus Cell ${ }^{\mathrm{F}}$ imaging software. Fifteen random fields with a good distribution of cells (10-100) were counted for each probe and sample.

\section{Anaerobic culture}

Aliquots (10 and $100 \mu \mathrm{l})$ of each sponge and sediment homogenate were spread onto standard Nutrient Agar, diluted Marine Agar (1/5 strength Marine Agar 2216 diluted with Artificial Seawater and supplemented with agar to a final concentration of $1.5 \%(\mathrm{w} / \mathrm{v}))$, Brain-Heart Infusion agar, BrainHeart Infusion agar with Artificial Seawater and Sabouraud Dextrose Agar plates in triplicate. Plates were incubated at ambient temperature in screw top 2.5-1 anaerobic jars containing one sachet of anaerobic atmosphere generator (Oxoid, Basingstoke, UK). The jars were further sealed in clear plastic bags filled with $\mathrm{N}_{2}$. Once back on shore, all samples were immediately transferred to an anaerobic chamber (Coy, Grass Lake, MI, USA). Bacterial growth was monitored for 4 weeks and individual colonies with unique morphotypes were serially streaked on their respective medium until pure cultures were obtained. Pure cultures were then transferred to diluted Marine Agar plates before DNA isolation. Pure cultures on diluted Marine Agar plates were also used to check cultures for aerobic growth by aerobic incubation at ambient temperature for a maximum of 4 weeks. For long-term storage, purified bacterial isolates were grown in 10-ml Marine Broth 2216 and 1-ml aliquots were frozen in $10 \%\left(\mathrm{v} / \mathrm{v}\right.$, final concentration) glycerol at $-80^{\circ} \mathrm{C}$.

DNA extraction and PCR of cultured bacterial isolates DNA of bacterial isolates was extracted by touching the colony with a sterile needle, which was then placed in $10 \mu \mathrm{l}$ sterile $5 \%(\mathrm{w} / \mathrm{v})$ Chelex (BioRad) solution. Samples were boiled for $10 \mathrm{~min}$ before centrifugation at $14000 \times g$. Supernatant containing extracted DNA was transferred to a new tube and stored at $-80^{\circ} \mathrm{C}$ before further use. Eubacterial universal primers FC27 (5'-AGAGTTTGATCCTGGC TCAG-3') and RC1492 (5'-TACGGCTACCTTGTTAC GACTT-3') (Mincer et al., 2004) were used to amplify the $16 \mathrm{~S}$ ribosomal DNA in standard PCR reactions containing $10 \mathrm{pmol}$ of each primer, $12.5 \mu \mathrm{l}$ IQ Supermix (BioRad), and sterile $\mathrm{H}_{2} \mathrm{O}$ to a final volume of $24 \mu \mathrm{l}$. The PCR mix was added to $1 \mu \mathrm{l}$ of DNA template and cycled as follows: initial denaturing at $95^{\circ} \mathrm{C}$ for $5 \mathrm{~min}, 35$ cycles at $95^{\circ} \mathrm{C}$ for 


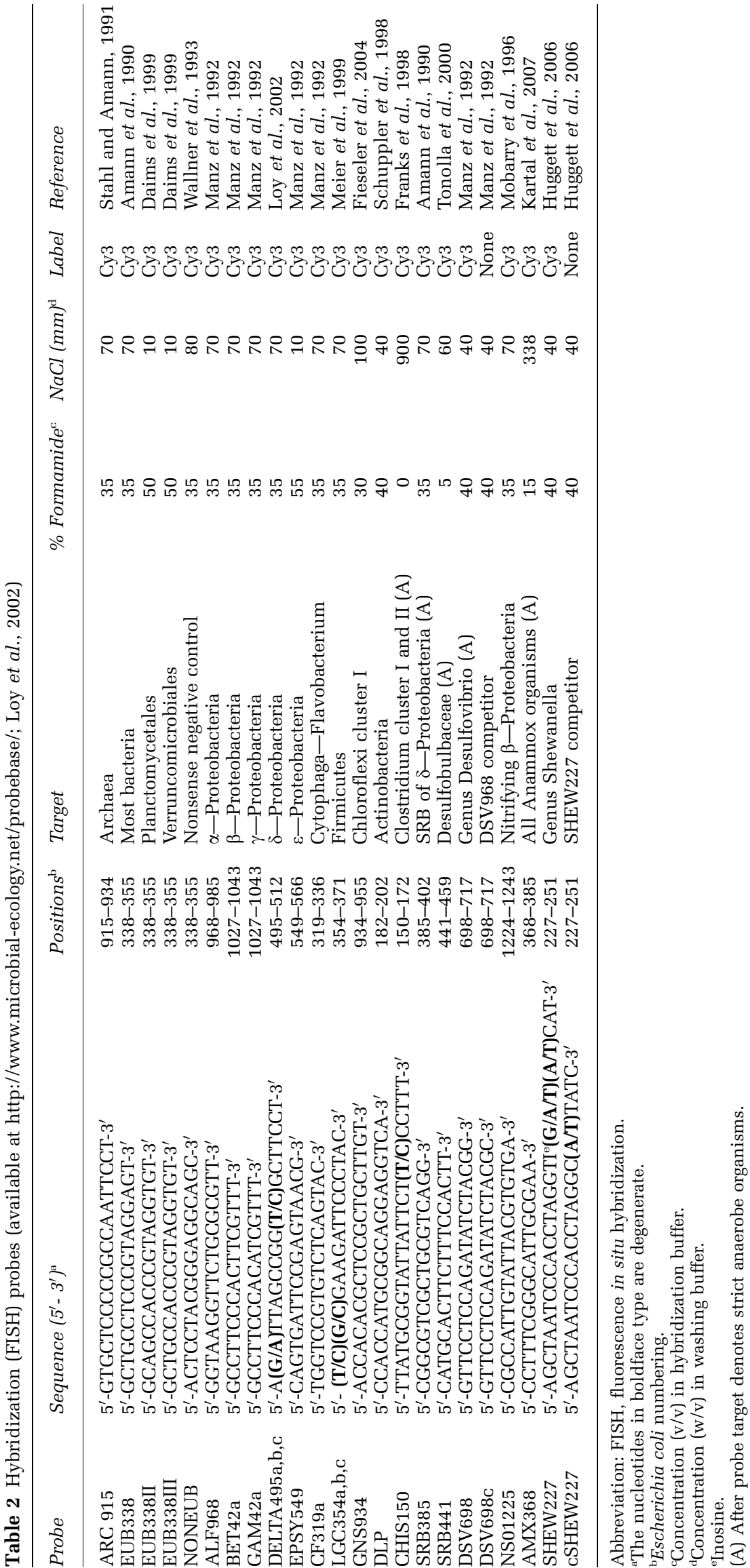


$30 \mathrm{~s}, 55^{\circ} \mathrm{C}$ for $30 \mathrm{~s}$ and $72{ }^{\circ} \mathrm{C}$ for $1.5 \mathrm{~min}$. A final extension of $7 \mathrm{~min}$ at $72^{\circ} \mathrm{C}$ was added. Each PCR product was checked by gel electrophoresis. Expected PCR amplicons of the correct size ( $\sim 1.5 \mathrm{kbp}$ ) were manually excised and gel purified using the Minelute gel extraction kit (Qiagen, Valencia, CA, USA). The PCR products were screened and grouped by restriction fragment length polymorphism analysis using HhaI restriction patterns (data not shown). PCR products from each restriction fragment length polymorphism group and those cultures with unique morphotypes were sequenced by Northwoods DNA (Solway, MN, USA). The $16 \mathrm{~S}$ recombinant DNA sequences were viewed and edited in Chromas (Technelysium, Tewantin, Australia). Sequences were identified using BLAST $\mathrm{N}$ at the NCBI database (www.ncbi. nlm.nih.gov, Altschul et al., 1997)

\section{Phylogenetic reconstruction}

All phylogenetic reconstruction was performed using ARB (Ludwig et al., 2004). Alignments of $16 \mathrm{~S}$ small subunit (SSU) ribosomal RNA sequences were made with the ARB fast alignment tool and were checked manually before being added to the ARB data set using the Arb_Parsimony tool to select suitable outgroups. De novo trees were constructed using the ARB neighbor-joining distance matrix with Felsenstein correction and termini (parameters: .- =0) and position variance (parameters: 123456789. $-=0$ ) filters (Felsenstein, 1988). The most appropriate DNA substitution model for distance analyses was determined by MODELTEST (Posada and Crandall, 1998). New sequences generated in this study were submitted to GenBank under the following accession numbers: EF114127-EF114207 and EU203318EU203332.

\section{Results}

Three deep-water sponge specimens used for this study were collected in August 2005 with Harbor Branch Oceanographic Institute's JSL research submersible from the support vessel R/V Seward Johnson (Table 1). A taxonomic voucher specimen is deposited for each at the Harbor Branch Oceanographic Museum: catalog numbers 003:01040, 003:01041 and 003:01042.

Specimen 003:01040 was collected (dive number JSL I-4820) in the Straits of Florida, 13-nm offshore southeastern Florida at a depth of $304 \mathrm{~m}$ from a rocky slope of the Miami Terrace escarpment. The specimen is pear-shaped, $\sim 20$-cm tall, with a single 5-cm apical osculum. It is light brown in color; the apical tip is lighter with alternating brown and white stripes around the osculum. The striped area of the osculum is hispid with 2 - to $3-\mathrm{mm}$ fringing spicules. The surface is hard, smooth and finely pitted, forming a detachable ectosomal cortex 2- to 3-mm thick. The specimen fits the description of the genus Geodia Lamarck, 1815 (Phylum- Porifera, Class- Demospongiae, Order- Astrophorida; Hooper and Van Soest, 2002).

Specimen 003:01041 was collected (dive JSL I-4826) from the Miami Terrace escarpment, $\sim 30 \mathrm{~nm}$ south of the first specimen and at a depth of $341 \mathrm{~m}$. It also fits the description of the genus Geodia but is a different species than the previous. The specimen is oblong to subspherical, $\sim 11-\mathrm{cm}$ maximum diameter, and has a gray to light brown color in situ. The hard detachable ectosomal cortex is 2- to $3-\mathrm{mm}$ thick and the surface is dimpled. Three oscula are $4 \mathrm{~mm}$ in diameter and slightly raised on 4-mm cones.

Specimen 003:01042 was collected (dive JSL I-4829) further south in the Straits of Florida off the Florida Keys on the Pourtales Terrace at a depth of $197 \mathrm{~m}$. It also fits the description of the genus Geodia but is also an unknown species that is different from the other two specimens. It is a flattened sphere $\sim 25 \mathrm{~cm}$ in diameter and $15-\mathrm{cm}$ tall. The hard 2-mm ectosomal cortex is hispid, covered with 2- to 5-cm long spicules and highly sedimented.

Analysis of homogenates by FISH showed that a wide variety of microbes, including some putative anaerobes are present in both Geodia spp. and sediments (Figure 1). Archaea were present at $1 \times 10^{6}$ cells g $^{-1}$ of sample (wet weight) while the total bacterial population was $1 \times 10^{8}$ cells g $^{-1}$ of sample. Gammaproteobacteria and Firmicutes gave the most signals in both sediment and Geodia spp. samples. Clostridium spp. and Shewanella spp. constituted only a minor part on the total Firmicutes and gammaproteobacterial population, respectively. In contrast, SRB were shown to be a significant part of the deltaproteobacterial population (between 30 and $87 \%$ ) for both sample types. Anammox organisms made up between 0.65 and $2.4 \%$ of the overall population. Betaproteobacterial ammonia-oxidizing bacteria made up between 12 and $57 \%$ of the overall betaproteobacterial population. Although Chloroflexi were present at $1 \times 10^{7}$ cells $^{-1}$ of sample in Geodia spp., there was a significantly $(P>0.005)$ smaller number of Chloroflexi present in sediment samples with $1.5 \times 10^{5}$ cells g $^{-1}$ of sample.

A total of 96 bacterial isolates from sediment and Geodia spp. were derived using standard anaerobic bacterial techniques on four different microbial media, which varied in $\mathrm{pH}$, nutrient content and ionic strength (salt content) to mimic different bacterial micro-environments (Tables 3a,b, Figure 2). A majority of the microbial isolates presented here, grew exclusively on a single medium type. All bacterial isolates were analyzed by classical microbiological and genetic methods, including determination of cell morphology, gram staining and $16 \mathrm{~S}$ ribosomal RNA gene sequence analysis.

Fifty unique organisms from three Geodia spp. specimens (Table 3a, Figure 2) were found in 
Average $\log _{10} \mathrm{cfu} / \mathrm{g}$

Sediment

(A) SRB of $\delta$-Proteobacteria (SRB 385)

(A) Desulfobulbaceae (SRB 441)

(A) Desulfovibrio sp.(DSV 698 + DSV 698 comp)

$\varepsilon$-Proteobacteria (EPSY549)

Firmicutes (LGC 354suite)

(A) Clostridium cluster I and II(CHIS 150) Cytophaga-Flavobacterium (CF 319a) Actinobacteria (DLP)

Chloroflexi cluster I(GNS 934)

Geodia sp.

Total counts (SYTO 9) Archaea (ARC 915)

Eubacteria (EUB 338)

Planctomycetales (EUB 338 II)

Verrucomicrobiales (EUB 338 III)

$\alpha$-Proteobacteria (ALF 986)

$\beta$-Proteobacteria (BET 42a)

Nitrifying $\beta$-Proteobacteria(NSO1225)

(A) All Anammox Organisms (AMX368)

$\gamma$-Proteobacteria (GAM 42a)

Shewanella sp. (SHEW 227 + SHEW 227 comp)

$\delta$-Proteobacteria (DELTA 495a,b,c)

(A) SRB of $\delta$-Proteobacteria (SRB 385)

(A) Desulfobulbaceae (SRB 441)

(A) Desulfovibrio sp.(DSV 698 + DSV 698 comp)

$\varepsilon$-Proteobacteria (EPSY549)

Firmicutes (LGC 354suite)

(A) Clostridium cluster I and II (CHIS 150)

Cytophaga - Flavobacterium (CF 319a)

Actinobacteria (DLP)

Chloroflexi cluster I (GNS 934)
4.004 .505 .005 .506 .006 .507 .007 .508 .008 .509 .00

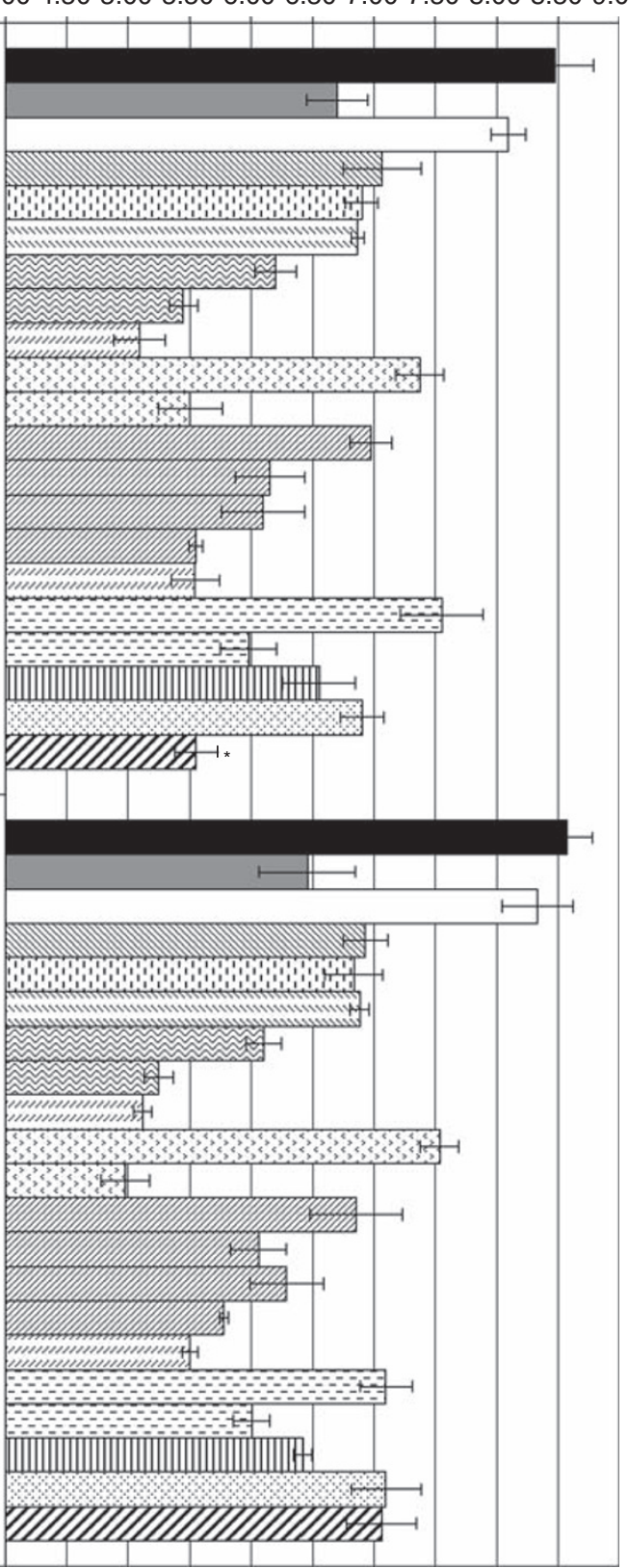

Figure $1 \log _{10}$ average populations of Eubacteria associated with sediment and Geodia spp. samples estimated by means of FISH counting. Error bars are \pm one s.d. Log cells ${ }^{-1}$ is the logarithmic (base 10) count of cells (bacteria) per gram of sample (wet weight). *Indicates a significant difference $(P<0.005)$ between Geodia spp. and sediment populations. (A) In front of probe target denotes strict anaerobe organisms.

anaerobic culture of which Firmicutes (22 isolates, $44 \%)$ represented the largest organism cluster. Gammaproteobacteria formed the second largest bacterial group in overall microbial diversity, comprising $40 \%$ (20 isolates) of all bacterial isolates. Minor culturable components of the microbial isolates consisted of Chloroflexi (one isolate, $2 \%$ ), Actinobacteria (three isolates, 6\%), Betaproteobacteria (three isolates, 6\%) and Bacteroidetes (one isolate, $2 \%$ ). With the exception of six obligate anaerobic organisms (WMB24A-E, W060), all bacteria were facultative anaerobes. A total of 46 isolates were $96-100 \%$ homologous to GenBank sequences; four were 91-95\% homologous. Bacillus spp. were the most abundant organisms found in culture comprising 11 isolates (22\%). Vibrio spp. were represented with 10 isolates $(20 \%)$, while Staphylococcus spp. were represented by 4 isolates (8\%).

Surprisingly, the phylogenetic analysis (Figure 3) of the cultured Chloroflexi species found in this 


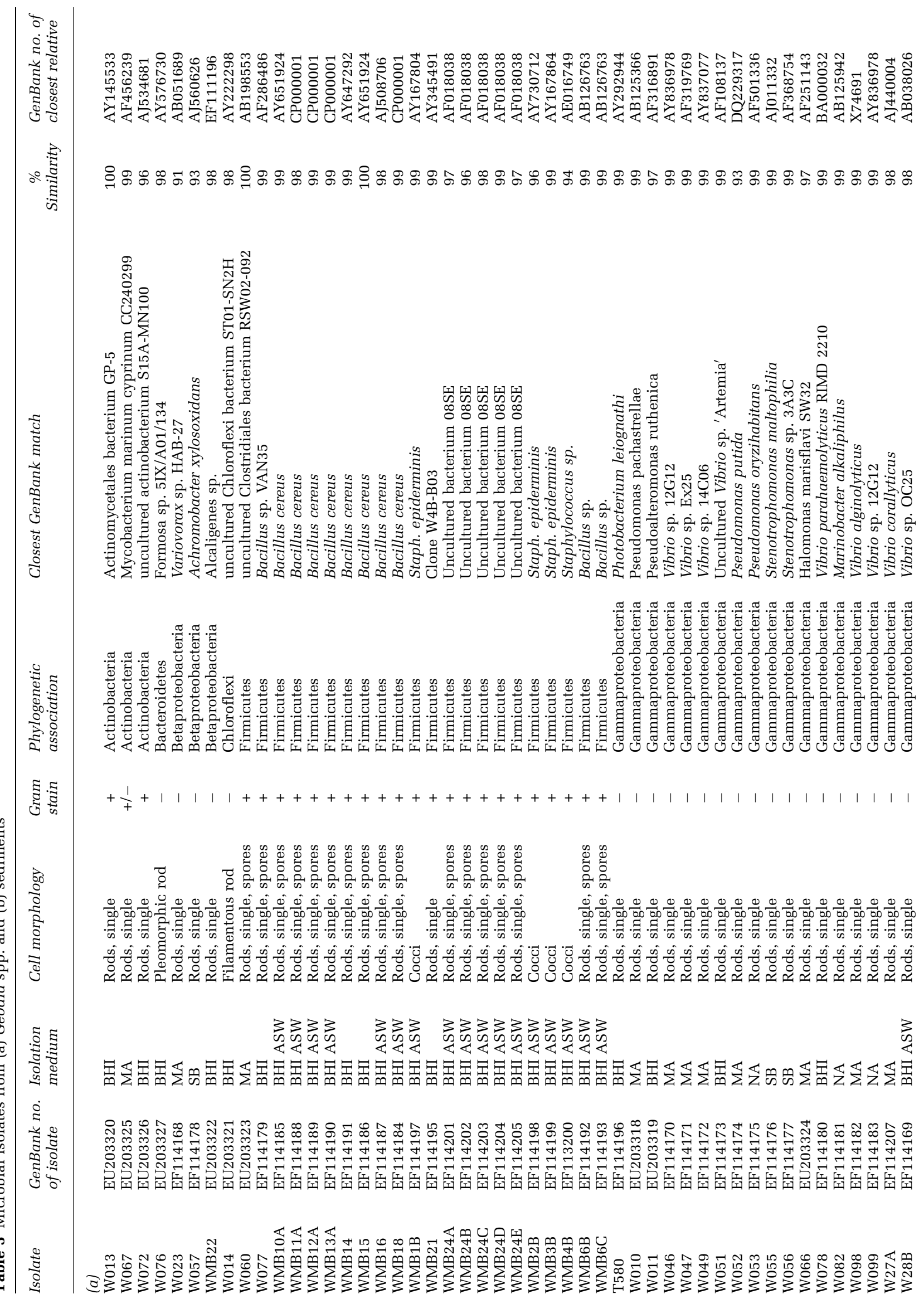




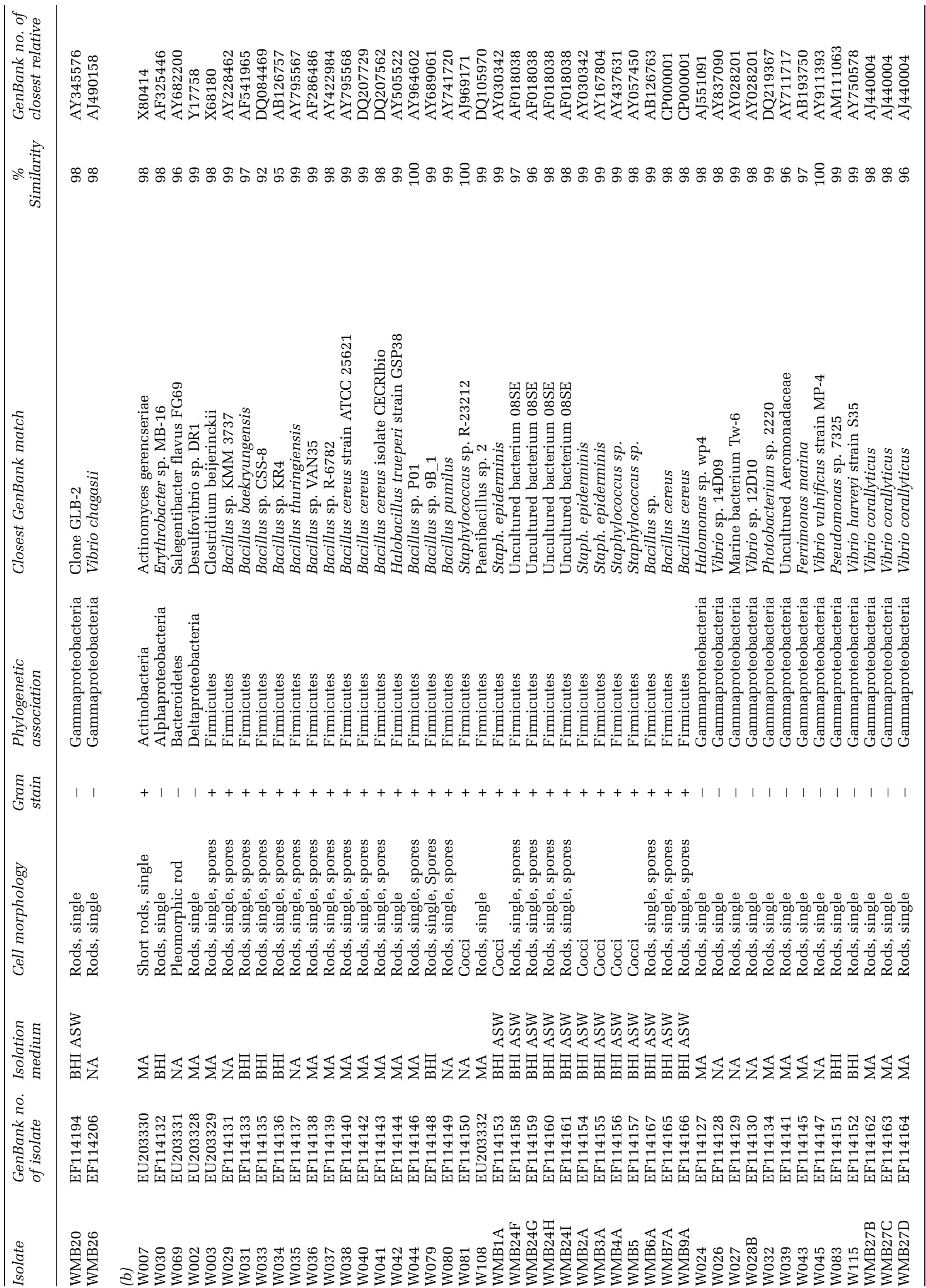




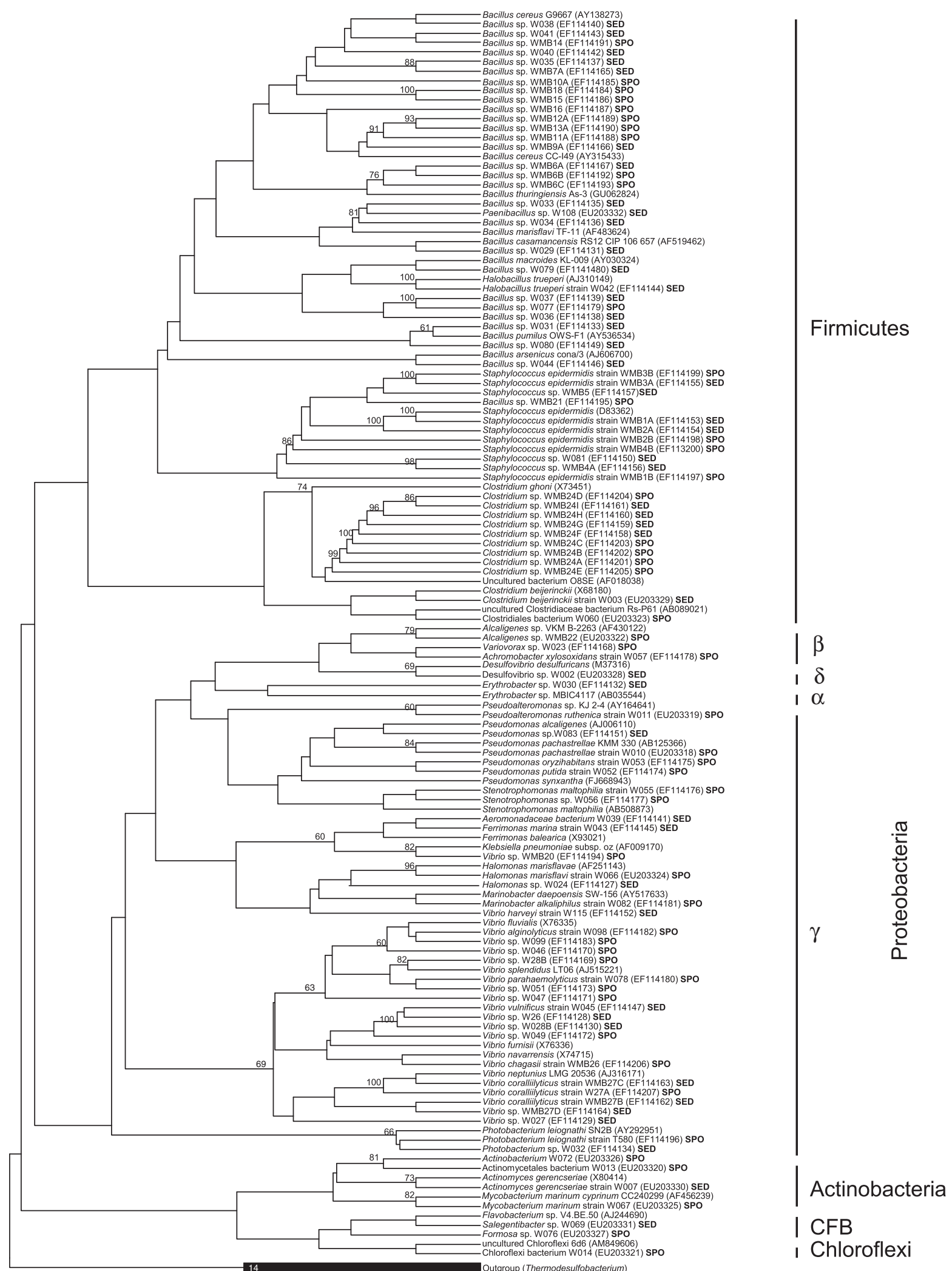

0.10

Figure 2 Distance-based neighbor-joining phylogeny of 16S ribosomal RNA (rRNA) gene sequences obtained from anaerobic isolates from sediment and sponge tissue. Numbers at nodes are percentages indicating levels of bootstrap support, based on neighbor-joining analysis of 1000 re-sampled data sets. Only values $\geqslant 60 \%$ are shown. Scale bar represents 0.1 substitution per nucleotide position. $\mathrm{SPO}=$ Isolate from Geodia spp., SED = Isolate from sediment. 


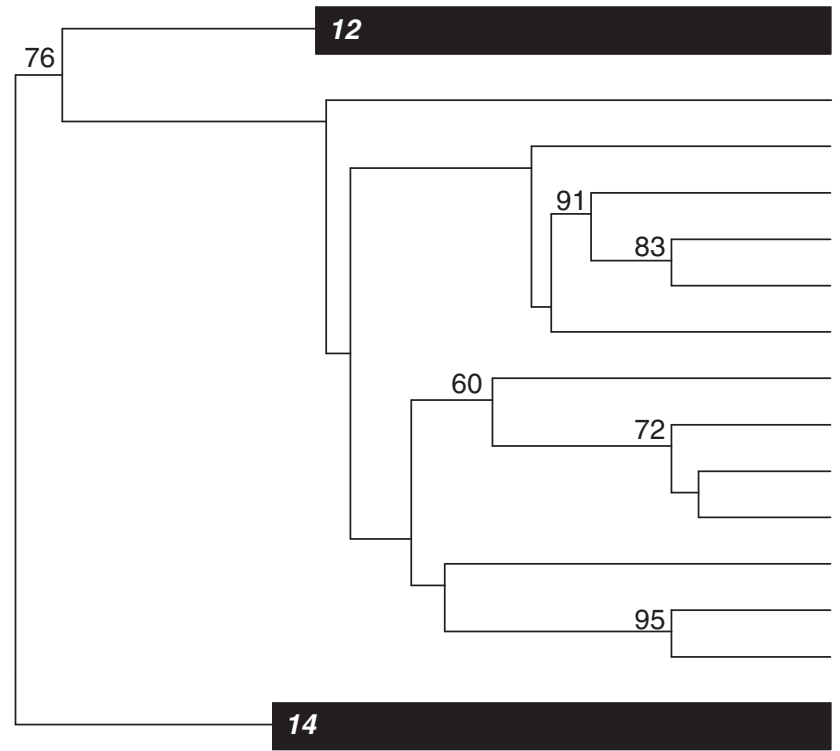

Chloroflexi

uncultured Chloroflexi 9m05AISF08 (EF629773)

Uncultured Chloroflexi bacterium clone 263 (AY485298)

Uncultured Chloroflexi AnCha11f (EF076229)

Uncultured Chloroflexi E137 (FJ529348)

Uncultured Chloroflexi Dd-spT-92 (AY897076)

uncultured sponge symbiontPAWS52f (AF186417)

Chloroflexi bacterium W014 (EU203321)

Uncultured Chloroflexi bacterium clone E152 (FJ529349)

uncultured Chloroflexi MB23 (EU919079)

uncultured Chloroflexi 6d6 (AM849606)

Uncultured Chloroflexi bacterium clone A31 (FJ529269)

uncultured bacterium TK16 (AJ347035)

uncultured bacterium TK35 (AJ347043)

Outgroup (Thermodesulfobacterium)

0.10

Figure 3 De novo neighbor-joining phylogeny comparing the Chloroflexi isolated from Geodia spp. in this study (EU203321) with other sponge-origin reference sequences. Numbers at nodes are percentages indicating levels of bootstrap support, based on neighbor-joining analysis of 1000 re-sampled data sets. Only values $\geqslant 60 \%$ are shown. Scale bar represents 0.1 substitution per nucleotide position. Reference sequences derived from previous studies and GenBank entries are described in the text or are written with their corresponding accession numbers.

study indicated a close relationship to a cluster of unculturable marine-derived Chloroflexi, which have been suggested to form stable symbiotic relationships with sponges (Taylor et al., 2007). In contrast, the cultured Chloroflexi species only showed a distant relationship with other Chloroflexi 16S RNA sequences found in the NCBI database. This current data infers that the organism isolated in this study forms a symbiotic relationship with deep-water sponges of the genus Geodia spp. To our knowledge this is the first evidence of a culturable member of the Chloroflexi isolated from a deep-water sponge.

Sediment samples used in this study had a grayish-green to black appearance and a fine sand grain structure. Anaerobic culture of sediment samples (Tab. 3b, Figure 2) again showed a wide array of organisms able to grow anaerobically, with a total of 46 isolates. Again, Firmicutes represented the largest group (63\%, 29 organisms), while Gammaproteobacteria were the second largest group (28\%, 13 organisms). One species $(2 \%)$ each of Actinobacteria, Alphaproteobacteria, Bacteroidetes and Deltaproteobacteria was also present. With the exception of six obligate anaerobic organisms (WMB24F-I, W002, W003), all bacteria were facultative anaerobes. Forty-four isolates were 96-100\% homologous to GenBank sequences. One isolate (Bacillus spp.) showed 92\% homology to GenBank sequences while another was 95\% (Bacillus spp.) homologous, which may indicate that these organisms are novel variants of the species Bacillus spp., which represented the major bacterial cluster found in sediment cultures amounting to 16 specimens
(34\%). Vibrio spp. was represented by seven isolates $(15 \%)$. Staphylococcus spp. was represented with four isolates $(9 \%)$.

In both the sponge and sediment samples, most sequences obtained from obligate anaerobes were most closely associated with uncultured bacterium 08SE (accession number AF018038) from the gut of the Tyrolean iceman (Cano et al., 2000). BLAST analysis further revealed the sequence to be a member of the Clostridium spp. Although these isolates are related to the same GenBank database entry, they differed in a combination of other parameters linked to their analysis set. Each culture was either isolated from a different growth medium and/or showed marked differences in gross colony morphology and color. As different bacterial strains can have a divergent biochemical and genetic makeup, these are included in the data presented here. Extensive morphological studies identified the organisms as obligate anaerobic, Gram positive, spore forming (sub-terminal to terminal) single rods, indicating the presence of a Clostridium spp.

\section{Discussion}

Although it is assumed that sponge-bacterium symbioses have existed for millions of years, the mechanisms by which this association is established are not well understood (Taylor et al., 2007). It may be assumed that microorganisms capable of association with sponges are present in the surrounding seawater and environment, but at abundances below 
the detection limit of currently available methods (Müller and Müller, 2003). Therefore, as anaerobic bacteria are not major components of the bacterial communities of seawater, resuspended sediment particles are a likely source for these and other microbiota. To enable the in situ assessment of microbial consortia in the deep-water sponge Geodia spp. and in surrounding sediment samples, we have utilized a combination of FISH with a diverse oligonucelotide probe set and direct microbial culture, which offered the possibility of characterizing microbes using traditional microbiological techniques. These methodologies have been proven to give a reliable overview of in situ microbial associations in various marine organisms, including sponges (Hoffmann et al., 2006; Brück et al., 2007). Our assessment of specimens of Geodia spp. and sediment showed that a significant proportion of microbiota is shared between the two. In fact, only Chloroflexi were present in significantly larger numbers in Geodia spp. in comparison with sediment. The major bacterial constituents Gammaproteobacteria, Actinobacteria and Firmicutes as well as anaerobic microbiota such as SRB and Clostridium spp. were present in similar numbers in Geodia spp. and sediment. Similar results were observed by Hoffmann et al. (2006) who showed that $G$. barretti is dominated by Alphaproteobacteria and Gammaproteobacteria.

Studies with the Adriatic sponge Suberites domuncula have suggested that oxygen levels within the sponge tissue are responsible for regulating the resident microbiota (Müller et al., 2004). Bacillus strains represent approximately $20 \%$ of the total heterotrophic microbiota in seawater whereas they constitute up to $80 \%$ of the total number of the culturable heterotrophic bacteria in marine sediments (Harwood, 1989). Similarly, Bacillus subtilis and Bacillus pumilus were the most abundant species among those associated with marine sponges (Ivanova et al., 1992, 1999). Spores of Bacillus and Clostridium species are metabolically dormant and extremely resistant to acute environmental stresses such as low nutrient availability and varying oxygen concentrations (James et al., 2000). Therefore, it is possible that spores of Bacillus and Clostridium species can survive for many years in marine sediments and sponge tissues until conditions are right for germination and formation of a metabolically active cell. In our study, Bacillus spp. constituted $40 \%$ of the total culturable sediment microbiota and $22 \%$ of culturable sponge associated microorganisms. FISH probing resulted in the detection of significant numbers of Clostridium spp. and other Firmicutes. Numbers in FISH did not vary significantly between sponge tissue and sediment. This suggests that these organisms were indeed viable within the examined environments.

The facultative nature of the majority of microbes isolated from sediment and Geodia spp. suggests that an anaerobic metabolism may not be a necessary survival strategy for most of the microbiota in sponges and marine sediments, however, it may provide a mechanism for coping with periods of anaerobiosis. The efficient utilization and recycling of nutrients, as previously found in Geodia spp., may rely on anoxic cycles within sponge tissue making symbiotic microorganisms capable of anaerobic metabolism an important factor in sponge survival (Schumann-Kindel et al., 1997). Furthermore, anoxic zones in Geodia spp. may have developed as an effective buffer system that prevents sulfide toxification and overgrowth of SRB (Hoffmann et al., 2006). Members of the Alphaproteobacteria, Betaproteobacteria, Gammaproteobacteria and Bacteroidetes have also been shown to have a critical role in extending the anaerobic oxidation of ammonium and nitrite to nutrient-depleted suboxic water layers by creating anoxic, nutrient-enriched microniches (Woebken et al., 2007). This niche-formation may also occur in sponges such as Geodia spp. and hence may have an important role in the removal and bioconversion of dissolved nitrogenous waste products such as nitrite, ammonia and organic detritus (marine snow; Hoffmann et al., 2005). Therefore, Geodia spp. may rely on external organic nitrogen sources in addition nitrogen-fixing symbionts for growth and tissue remodeling. As nitrogen is the limiting growth factor for biomass formation in nutrient poor environments, sponges rely on prokaryotic symbionts with specific nitrogen recycling strategies to prevent enduring nutrient stress (Meier et al., 1994; Zehr and Ward, 2002; Lenton and Klausmeier, 2006). The annamox bacterial group is capable of converting nitrite and ammonia to nitrogen, which can be fixed to organic intermediates by subsequent microbial processes (Taylor et al., 2007). Furthermore, a consolidated formation of organic nitrogen intermediates by prokaryotic ammonia and nitrite oxidizers may lead to intermediates that can be assimilated by the sponge host leading to complete nitrogen cycling within a sponge (Taylor et al., 2007). In this study, annamox organisms were found in Geodia spp. and sediment samples suggesting that bioconversion and nutrient cycling of nitrogenous compounds may occur in these samples.

It has been suggested that the nutrient exchange between sponge host and microbial symbiont may also be driven by the sponge restricting the symbiont's access to essential nutrients and thus supplying the host with an excess of organic carbon (Hinde, 1988; Wilkinson, 1992). In shallow water sponges, cyanobacteria have been identified as the dominant symbionts responsible transfer of photosynthetically derived organic carbon compounds mainly in form of glycerol (C3) for metabolism in the sponge host (Wilkinson, 1980, 1983). In addition to cyanobacteria, a specific cluster of the bacterial class Chloroflexi has been identified as sponge-specific symbionts, which is also supported by our data (Figures 1 and 3, Hentschel et al., 2002; Taylor et al., 2007). However, a possible interaction of these 
microbes with the sponge host has so far not been suggested. Much like cyanobacteria, Chloroflexi are filamentous microorganisms, which are capable of permanently integrating into sponge tissue. In light suffused shallow water environments Chloroflexi are also capable photosynthetic fixation of atmospheric $\mathrm{CO}_{2}$. On the basis of the similar metabolic capacities between cyanobacteria and chloroflexi, these bacteria may also provide carbonaceous photosynthates, such as glycerol, to the sponge host in shallow water environments.

Although symbiotic cyanobacteria cannot thrive in light-deprived environments (Thacker, 2005), Chloroflexi can metabolically adjust to dark, nutrient poor environments such as the deep ocean. FISH data sets reported in this study showed significantly higher counts of Chloroflexi in the tissue of Geodia spp. when compared with marine sediment samples. This data indicating that deep-water Geodia tissue is enriched with Chloroflexi points to a potential symbiotic relationship. Previous studies of Chloroflexi sponge interactions were complicated by the fact that none of the Chloroflexi species could be recovered in culture for more detailed microbiological studies. To our knowledge, this study presents the first account of a culturable marine bacterium of the class Chloroflexi isolated from sponge tissue. Comparative phylogenetic analysis of this isolate with database DNA sequences of unculturable Chloroflexi suggested that this organism may actually form a true symbiotic relationship with deep-water sponge hosts (Hentschel et al., 2002). Chloroflexi can convert inorganic into organic carbon by way of the 3- hydroxyproprionate pathway (Brock et al., 1984). The resulting organic intermediates produced by this microbial symbiont could subsequently be transferred to the host sponge and metabolized, which would impart a clear synergistic survival advantage to the host in nutrient poor environments such as the deep ocean floor. The Chloroflexi-catalyzed conversion of inorganic $\mathrm{CO}_{2}$ to metabolizable organic intermediates certainly contributes to microbial biomass formation in deep-water environments. The inferred symbiotic relationship of Chloroflexi may also contribute to additional biomass formation in deep-water Geodia species.

In conclusion, as marine microorganisms survive under harsh environmental conditions, they can be expected to be a source of novel biogeochemical and biochemical processes (Barlet et al., 1995; Turley, 2000). Through this study, it has become evident that sponge and sediment microbiota share a striking overall similarity and that facultative and obligate anaerobic microorganisms thrive in these environments, in which they may aid in nutrient recycling and bioconversion or some other, to date unknown, function. Resuspended sediment particles may further form a realistic source, in addition to vertical transfer, of microorganisms able to associate or form a symbiotic relationship with sponges. Such microbes represent another facet of the cultivable microbiota that remains to be examined for its biotechnological potential.

\section{Acknowledgements}

Wolfram Brück was funded through a postdoctoral fellowship from the Link Foundation. Research expeditions were funded by the State of Florida through the Center of Excellence in Biomedical and Marine Biotechnology and by the State of Florida, Fish and Wildlife Research Initiative, 'Florida Ocean's Initiative- The Drug Discovery Initiative'. The experiments comply with the current laws of the United States. This is HBOI contribution number 1800.

\section{References}

Altschul SF, Madden TL, Schäffer AA, Zhang J, Zhang Z, Miller W et al. (1997). Gapped BLAST and PSI-BLAST: a new generation of protein database search programs. Nucl Acid Res 25: 3389-3402.

Amann RI, Binder BJ, Olson RJ, Chisholm SW, Devereux R, Stahl DA. (1990). Combination of $16 \mathrm{~S}$ rRNA-targeted oligonucleotide probes with flow cytometry for analyzing mixed microbial populations. Appl Environ Microbiol 56: 1919-1925.

Barlet DH, Kato C, Horikoshi K. (1995). High pressure influences on gene and protein expression. Res Microbiol 146: $697-706$.

Brock TD, Madigen MT, Martinko JM, Parker J. (1984). Biology of Microbiology. Prentice Hall, International (UK): London.

Brück TB, Brück WM, Santiago-Vázquez LZ, McCarthy PJ, Kerr RG. (2007). Diversity of the bacterial communities associated with the azooxanthellate deep water octocorals Leptogorgia minimata, Iciligorgia schrammi, and Swiftia exertia. Mar Biotech 9: 561-576.

Cano RJ, Tiefenbrunner F, Ubaldi M, Del Cueto C, Luciani S, Cox T et al. (2000). Sequence analysis of bacterial DNA in the colon and stomach of the Tyrolean Iceman. Am J Phys Anthropol 112: 297-309.

Colquhoun JA, Heald SC, Li L, Tamaoka J, Kato C, Horikoshi K et al. (1998). Taxonomy and biotransformation activities of some deep-sea actinomycetes. Extremophiles 2: 269-277.

Daims H, Brühl A, Amann R, Schleifer K-H, Wagner M. (1999). The domain-specific probe EUB338 is insufficient for the detection of all Bacteria: development and evaluation of a more comprehensive probe set. Syst Appl Microbiol 22: 434-444.

Dalsgaard T, Thamdrup B, Canfield DE. (2005). Anaerobic ammonium oxidation (anammox) in the marine environment. Res Microbiol 156: 457-464.

Duckworth AR, Bruck WM, Janda KE, Pitts TP, McCarthy PJ. (2006). Retention efficiencies of the coral reef sponges Aplysina lacunosa, Callyspongia vaginalis and Niphates digitalis determined by Coulter counter and plate culture analysis. Mar Biol Res 2: 243-248.

Felsenstein J. (1988). Phylogenies from molecular sequences: inference and reliability. Ann Rev Gen 22: 521-565.

Fieseler L, Horn M, Wagner M, Hentschel U. (2004). Discovery of the novel candidate phylum 'Poribacteria' in marine sponges. Appl Environ Microbiol 70: 3724-3732. 
Franks AH, Harmsen HJM, Raangs GC, Jansen GJ, Schut F, Welling GW. (1998). Variations of bacterial populations in human feces measured by fluorescent in situ hybridization with group-specific 16S rRNA-targeted oligonucleotide probes. Appl Environ Microbiol 64: 3336-3345.

Gruber G, Reitner J. (1991). Isolated poriferan micro- and megascleres from the lower Campanian of Höver (northern Germany) and remarks on the phylogeny of the taxon Geodiidae (Demospongiae). Berliner Geowissenschaftliche Abhandlungen (A) 134: 107-117.

Harwood CR. (1989). Biotechnology Handbooks 2: Bacillus. Plenum Press: New York.

Hentschel U, Hopke J, Horn M, Friedrich AB, Wagner M, Hacker J et al. (2002). Molecular evidence for a uniform microbial community in sponges from different oceans. Appl Environ Microbiol 68: 4431-4440.

Hinde R. (1988). Symbiotic nutrition and nutrient limitation. Proc 6th Int Coral Reef Symp 1: 199-204.

Hoffmann F, Larsen O, Rapp HT, Osinga R. (2005). Oxygen dynamics in choanosomal sponge explants. Mar Biol Res 1: 160-163.

Hoffmann F, Rapp HT, Reitner J. (2006). Monitoring microbial community composition by fluorescence in situ hybridization during cultivation of the marine cold-water sponge Geodia barretti. Mar Biotechnol (NY) 8: 373-379.

Hooper JNA, Van Soest RWM. (2002). Systema Porifera, a Guide to the Classification of Sponges Vol. 1 Kluwer Academic: New York. p 1101.

Huggett MJ, Williamson JE, de Nys R, Kjelleberg S, Steinberg PD. (2006). Larval settlement of the common Australian sea urchin Heliocidaris erythrogramma in response to bacteria from the surface of coralline algae. Oecologia 149: 604-619.

Ivanova EP, Mikhailov VV, Andreev LA. (1992). Marine bacilli and some approaches to their identification. Microbiol Zhurnal 54: 27-33.

Ivanova EP, Vysotskii MV, Svetashev VI, Gorshkova NM, Mikhailov VV, Yumoto N et al. (1999). Characterisation of Bacillus strains of marine origin. Intern Microbiol 2: 267-271.

James AL, Chilvers KF, Perry JD, Armstrong L, Gould FK. (2000). Evaluation of p-naphtholbenzene- $\beta$-D-galactoside as a substrate for bacterial $\beta$-galactosidase. Appl Environ Microbiol 66: 5521-5523.

Kartal B, Rattray J, van Niftrik LA, van de Vossenberg J, Schmid MC, Webb RI et al. (2007). Candidatus 'Anammoxoglobus propionicus' a new propionate oxidizing species of anaerobic ammonium oxidizing bacteria. Syst Appl Microbiol 30: 39-49.

Kato C, Li L, Tamaoka J, Horikoshi K. (1997). Molecular analysis of the sediment of the $11000 \mathrm{~m}$ deep Mariana Trench. Extromophiles 1: 117-123.

Lenton TM, Klausmeier CA. (2006). Co-evolution of phytoplankton C.N:P stochiometry and the deep ocean N: P ratio. Biogeosci Disc 3: 1023-1047.

Loy A, Lehner A, Lee N, Adamczyk J, Meier H, Ernst J et al. (2002). Oligonucleotide microarray for $16 \mathrm{~S}$ rRNA gene-based detection of all recognized lineages of sulfate-reducing prokaryotes in the environment. Appl Environ Microbiol 68: 5064-5081.

Ludwig W, Strunk O, Westram R, Richter L, Meier H, Yadhukumar et al. (2004). ARB: a software environment for sequence data. Nucleic Acids Res 32: 1363-1371.

Luna GM, Dell'Anno A, Danovaro R. (2006). DNA extraction procedure: a critical issue for bacterial diversity assessment in marine sediments. Envir Microbiol 8: $308-320$.

Luna GM, Dell'Anno A, Guiliano L, Danovaro R. (2004). Bacterial diversity in deep Mediterranean sediments: relationship with the active bacterial fraction and substrate availability. Envir Microbiol 6: 745-753.

Manz W, Amann R, Ludwig W, Wagner M, Schleifer K-H. (1992). Phylogenetic oligodeoxynucleotide probes for the major subclasses of Proteobacteria: problems and solutions. Syst Appl Microbiol 15: 593-600.

Meier D, Zuniga-Partida V, Ramirez-Cano F, Hahn N-C, Faix O. (1994). Conversion of technical lignin into slow release nitrogenous fertilizers by ammoxidation in the liquid phase. Bioresource Technol 49: 121-128.

Meier H, Amann R, Ludwig W, Schleifer K-H. (1999). Specific oligonucleotide probes for in situ detection of a major group of gram-positive bacteria with low DNA G+C content. Syst Appl Microbiol 22: 186-196.

Mincer TJ, Spyere A, Jensen PR, Fenical W. (2004). Phylogenetic analysis and diterpenoid production by marine bacteria of the genus Saprospira. Curr Microbiol 49: 300-307.

Mobarry BK, Wagner M, Urbain V, Rittmann BE, Stahl DA. (1996). Phylogenetic probes for analyzing abundance and spatial organization of nitrifying bacteria. Appl Environ Microbiol 62: 2156-2162.

Müller WE, Grebenjuk VA, Le Pennec G, Schroder H, Brummer F, Hentschel U et al. (2004). Sustainable production of bioactive compounds by sponges-cell culture and gene cluster approach: a review. Mar Biotechnol 6: 105-117.

Müller WEG, Müller IM. (2003). Origin of the metazoan immune system: identification of the moleculaes and their function in sponges. Integr Comp Biol 43: 281-292.

Musat N, Werner U, Knittel K, Kolb S, Dodenhof T, van Beusekom JE et al. (2006). Microbial community structure of sandy intertidal sediments in the North Sea, Sylt-Rømø Basin, Wadden Sea. Syst Appl Microbiol 29: 333-348.

Posada D, Crandall KA. (1998). Modeltest: testing the model of DNA substitution. Bioinformatics 14: 817-818.

Purdy KJ, Nedwell DB, Embley TM, Takii S. (2001). Use of $16 \mathrm{~S}$ rRNA-targeted oligonucleotide probes to investigate the distribution of sulphate-reducing bacteria in estuarine sediments. FEMS Microbiol Ecol 36: 165-168.

Purdy KJ, Munson MA, Cresswell-Maynard T, Nedwell DB, Embley TM. (2003). Use of 16S rRNA-targeted oligonucleotide probes to investigate function and phylogeny of sulphate-reducing bacteria and methanogenic archaea in a UK estuary. FEMS Microbiol Ecol 44: 361-371.

Reiswig HM. (1981). Partial carbon and energy budgets of the bacteriosponge Verongia fistularis (Porifera: Demospongiae) in Barbados. Mar Ecol Prog Ser 2: 273-293.

Schmidt EW, Obraztsova AY, Davidson SK, Faulkner DJ, Haygood MG. (2000). Identification of the antifungal peptide-containing symbiont of the marine sponge Theonella swinhoei as a novel delta-Proteobacterium, 'Candidatus Entotheonella palauensis'. Mar Biol 136: 969-977.

Schumann-Kindel G, Bergbauer M, Manz W, Szewyk U, Reitner J. (1997). Aerobic and anaerobic microorganisms in modern sponges: a possible relationship to fossilization-processes. Facies 36: 268-272. 
Schuppler M, Wagner M, Schön G, Göbel U. (1998). In situ identification of nocardioform actinomycetes in activated sludge using fluorescent rRNA-targeted oligonucleotide probes. Microbiology 144: 249-259.

Skyring GW. (1987). Sulfate reduction in coastal ecosystems. Geomicrobiol J 5: 295-374.

Stahl DA, Amann RI. (1991). Development and application of nucleic acid probes. In: Stackebrandt E and Goodfellow M (eds). Nucleic Acid Techniques in Bacterial Systematics. John Wiley \& Sons Ltd: Chichester, England. pp 205-248.

Takii S, Fukui M. (1991). Relative importance of methanogenesis, sulfate reduction and dendritification in sediments of the lower Tama river. Bul Jpn Soc Micro Ecol 6: 1-8.

Taylor MW, Radax R, Steger D, Wagner M. (2007). Spongeassociated microorganisms: evolution, ecology, and biotechnological potential. Microbiol Mol Biol Rev 71: 295-347.

Thacker RW. (2005). Impacts of shading on sponge-cyanobacteria symbiosis: acomparision between host-sepcific and generalist associations. Intregr Comp Biol 45: 369-376.

Tonolla M, Demarta A, Peduzzi S, Hahn D, Peduzzi R. (2000). In situ analysis of sulfate-reducing bacteria related to Desulfocapsa thiozymogenes in the chemocline of meromictic Lake Cadagno (Switzerland). Appl Environ Microbiol 66: 820-824.

Turley C. (2000). Bacteria in the cold deep sea benthic boundary layer and sediment-water interface of the NE Atlantic. FEMS Microbiol Ecol 33: 89-99.

Vacelet J, Donadey C. (1977). Electron microscope study of the association between some sponges and bacteria. $J$ Exp Mar Biol Ecol 30: 301-314.

Wallner G, Amann R, Beisker W. (1993). Optimizing fluorescent in situ hybridization with rRNA-targeted oligonucleotide probes for flow cytometric identification of microorganisms. Cytometry 14: 136-143.

Wang F, Wang P, Chen M, Xiao X. (2004). Isolation of extremophiles with the detection and retival of Shewanella strains in deep-sea sediments from the West Pacific. Extremophiles 8: 156-168.

Webster NS, Hill RT. (2001). The culturable microbial community of the Great Barrier Reef sponge Rhopaloeides odorabile is dominated by an $\alpha$-Proteobacterium. Mar Biol 138: 843-851.

Wilkinson CR. (1978). Microbial association in sponges. II. Numerical analysis of sponge and water bacterial populations. Mar Biol 49: 169-176.

Wilkinson CR. (1980). Nutrient translocation from green algal symbionts to the freshwater sponge Ephydatia fluviatilis. Hydrobiologia 75: 241-250.

Wilkinson CR. (1983). Net primary productivity in coral reef sponges. Science 219: 410-412.

Wilkinson CR. (1992). Symbiotic interactions between marine sponges and algae. In: Reisser W (ed). Algae and Symbioses: Plants, Animals, Fungi, Viruses, Interactions Explored. Biopress Limited: Bristol, UK. pp 111-151. 478.

Wilkinson CR, Cheshire AC. (1990). Comparisons of sponge populations across the Barrier Reefs of Australia and Belize: evidence for higher productivity in the Caribbean. Mar Ecol Prog Ser 67: 285-294.

Woebken D, Fuchs BM, Kuypers MM, Amann R. (2007). Potential interactions of particle-associated anammox bacteria with bacterial and archaeal partners in the Namibian upwelling system. Appl Environ Microbiol 73: 4648-4657.

Zehr JP, Ward BB. (2002). Nitrogen cycling in the ocean: New perspectives on processes and paradigms. Appl Environ Microbiol 68: 1015-1024. 